\title{
INDÚSTRIA E DESENVOLVIMENTO: \\ EFEITOS DA REINVENÇÃO DE UM \\ TERRITÓRIO PRODUTIVO NO RIO DE JANEIRO
}

\author{
INDUSTRY AND DEVELOPMENT: \\ EFFECTS OF THE REINVENTION OF A \\ PRODUCTIVE TERRITORY IN RIO DE JANEIRO
}

\author{
José Ricardo Ramalho*
}

\section{Introdução}

Duas décadas se passaram - 1996-2015 - desde que o Sul Fluminense, região do Rio de Janeiro amplamente conhecida pela produção siderúrgica desde 1946, em razão da Companhia Siderúrgica Nacional (CSN), passou por uma reconfiguração de seu parque industrial com a implantação de fábricas do setor automotivo. Se a CSN tornou o município de Volta Redonda uma referência em termos de atividade mono -industrial, controlando seu espaço urbano e sua força de trabalho, o novo setor industrial, estimulado pelas vantagens fiscais oferecidas pelo estado e pelos municípios (especialmente Resende, Porto Real e Itatiaia) buscou deliberadamente localidades sem tradição operária e sindical, para instalar fábricas "enxutas" e adequadas a um novo perfil de empresa global. ${ }^{1}$ (RAMALHO e FORTES, 2012, RODRIGUES e RAMALHO, 2007).

Organizada internacionalmente, a cadeia produtiva da indústria de veículos tem passado por várias mudanças nas últimas três décadas, em função de crises de produtividade associadas à rigidez dos padrões fordistas e da necessidade de se articular em rede como forma de estabelecer um padrão produtivo menos verticalizado e flexível quanto às suas empresas fornecedoras e

\footnotetext{
* É professor titular do Departamento de Sociologia e do Programa de Pós-Graduação em Sociologia e Antropologia da UFRJ (Rio de Janeiro/RJ/Brasil). É pesquisador do CNPQ e da Faperj (Programa Cientistas do Nosso Estado) e coordenador do Grupo de Pesquisa do CNPQ "Desenvolvimento, trabalho e ambiente" (DTA-UFRJ). josericardoramalho@gmail.com.

1. Os dados utilizados neste texto são resultados parciais de projetos de pesquisa financiados pelo CNPq e pela Faperj (Cientistas do Nosso Estado). Sou grato a Jonas Bicev pela elaboração de gráficos e tabelas e a Roberto Véras de Oliveira pelos comentários e sugestões.
} 
às relações de trabalho no chão de fábrica. A esse conjunto de fatores se soma o desafio internacional de ocupar novos territórios produtivos, regionais e locais, como forma de recriar condições de crescimento. (FREYSSENET e LUNG, 1997).

Uma análise das estratégias industriais e de seu papel na indução de desenvolvimento econômico exige, portanto, uma reflexão sobre seus desdobramentos em localidades e regiões. Para Castells (1999, p. 407), "a globalização estimula a regionalização" e o "novo espaço industrial" se caracterizaria pela "capacidade organizacional e tecnológica de distribuir o processo produtivo em diferentes localizações [...].” (p. 412-419).

Este texto pretende, por meio da experiência de alguns municípios do Sul Fluminense, argumentar teórica e empiricamente contra interpretações que não valorizam as dinâmicas socioprodutivas que se articulam territorialmente a partir da presença de empresas que fazem parte de "redes globais de produção" e que postulam uma lógica de produção de excedente apenas voltada aos lucros e aos benefícios projetados pelos interesses de seus acionistas e de suas matrizes em outros lugares do mundo. Diferentemente, a proposta é trabalhar com uma perspectiva que considera o efeito da presença dessas empresas como contraditoriamente capaz de, a depender das ações dos atores estratégicos, estimular lógicas que resultem no crescimento de atividades econômicas, na redefinição de formas de poder regional e local, na reunião de forças políticas desarticuladas, na criação de novos compromissos entre firmas e na reestruturação do mercado de trabalho.

De acordo com Santos $(2011$, p. 131132), a multiplicidade de escalas em que atuam as empresas que fazem parte de RGP (nos planos local, regional, nacional e glo- bal), "construídas e transformadas ao longo do tempo por [...] agentes com influência e poder assimétricos", implica em considerar a influência dos "contextos sociopolíticos dentro dos quais elas estão enraizadas". Segundo Henderson et al. (2011, p. 153154), "empresas, governos e outros atores econômicos de diferentes sociedades às vezes têm prioridades diferentes vis-à-vis à lucratividade, ao crescimento, ao desenvolvimento econômico". Isto significa dizer que as implicações da rede de produção para as empresas e para o desenvolvimento econômico em cada local "não podem ser 'mensuradas' a partir da lógica de organização da rede e da distribuição de poder corporativo dentro dela" (p. 153-154). Para esses autores, "agentes diversos, oriundos igualmente de quadros sócio-institucionais variados, possuem prioridades diferentes e por isso, são dotados de autonomia"; embora a lógica da rede de produção tenha influência, "não determina a ação e as relações entre os agentes". (p. 156-159).

A proposta deste artigo é identificar e problematizar a "reinvenção" desse território produtivo já industrializado, a partir da implantação do setor automotivo, tomando como base dados estatísticos que apontam melhorias em índices econômicos, sociais e do mercado de trabalho, mas também confirmam o uso sistemático da mão de obra barata como característica marcante das práticas empresariais. Serão igualmente consideradas as inserções, as expectativas e as estratégias dos diversos agentes sociais por meio de uma combinação de interesses sustentados pelas grandes empresas multinacionais em busca de vantagens comparativas e de maior eficiência no processo de acumulação; pelos políticos estaduais, regionais e locais, com seus projetos de desenvolvimento regional; e, também, pelos sindicatos e pelos trabalha- 
dores confiantes na criação de mais oportunidades de emprego.

A repercussão dos novos investimentos da indústria automotiva no Sul Fluminense alterou substantivamente as atividades econômicas, políticas e administrativas regionais a partir de meados dos anos 1990. Foi nesse período, por exemplo, que o município de Porto Real (RJ) se emancipou administrativamente de Resende (RJ) para receber a fábrica da PSA Peugeot Citroën. Houve também um crescimento do mercado de trabalho formal, do ritmo de obras da construção civil e dos recursos arrecadados pelos municípios, com um rápido aumento dos PIB municipais. Da mesma forma, deu-se a formação de uma classe operária jovem, escolarizada e majoritariamente residente nas localidades onde se instalaram as novas fábricas, o que resultou na necessidade de revisão das estratégias políticas do Sindicato dos Metalúrgicos, em geral referentes aos problemas trabalhistas dos operários siderúrgicos do município vizinho de Volta Redonda (RJ).

A injeção de grandes somas de recursos financeiros incentivou também um debate sobre um projeto de desenvolvimento regional que explorasse a vocação metalmecânica introduzida pela vinda das grandes empresas e de suas fornecedoras. Incentivos fiscais, principalmente através da redução de impostos, foram utilizados como estratégia para atrair novos empreendimentos, como parte de um "novo regime automotivo" ${ }^{2}$ implementado pelo governo federal.

Ao longo desses últimos vinte anos, houve um adensamento das atividades li- gadas à indústria de veículos. No período inicial, a implantação da VW Caminhões, hoje MAN Latin America (1996), e, logo em seguida, da PSA Peugeot Citroën (2001), que trouxe para o seu entorno uma rede básica de empresas de autopeças e logística, conferiram credibilidade a um perfil regional que se consolidava como território produtivo voltado para novas experiências gerenciais e para se beneficiar de um período de crescimento desse setor econômico em todo o país.

A partir de 2010, apesar de uma conjuntura recessiva para o mercado de veículos, a região continuou a se beneficiar do que poderia ser chamado de uma "nova fase do regime automotivo": com a inauguração da fábrica de automóveis da Nissan em 2014, em Resende; o início da construção da planta da Land Rover (com previsão de término em 2016), em Itatiaia; além da vinda da Hyundai (2013), voltada para o setor de máquinas pesadas e da reforma e ampliação da Michelin, fabricante de pneus para veículos automotores.

\section{A indústria automotiva no Sul Fluminense}

A década de 1990 marcou a indústria automotiva brasileira com um intenso processo de reestruturação, após um longo período de crise e recessão econômica no mercado interno, associado ao acirramento da concorrência internacional e ao abandono da política de substituição de importações (ABREU; GITAHY; RAMALHO et al, 2000). Foi nesse contexto que se estabeleceu um

2. Como parte do Plano Real, o "novo regime automotivo" teve como objetivo consolidar e atrair investimentos para o setor: (1) mantendo em funcionamento as grandes montadoras e as indústrias de autopeças já instaladas no país; (2) reestruturando as empresas brasileiras do setor; (3) atraindo novas empresas e estimulando a construção de novas plantas e marcas; (4) consolidando o Mercosul e reforçando a posição do Brasil. 
"novo regime automotivo", com uma política de incentivos fiscais que resultou em um processo de reespacialização industrial, retomada de investimentos e a construção de novas fábricas em diversas regiões do país. As novas estratégias consideraram aspectos econômicos e políticos, evitando as regiões mais tradicionais na produção de veículos e mais experientes em termos de participação sindical, como era o caso do ABC paulista (ABREU e RAMALHO, 2003, p. 133-135).

Embora tenha havido uma grande inversão de recursos espalhados por vários municípios brasileiros (cerca de US\$ 10 bilhões), essa estratégia, denominada pelos governadores e autoridades federais, na época, de "pró-ativa”, causou uma disputa fiscal predatória entre estados e municípios (ARBIX, 2000, p. 42). A posição secundária do estado do Rio de Janeiro na distribuição geográfica da indústria automotiva no país desde sua implantação na década de 1950 serviu como argumento para que seus agentes públicos disputassem os novos investimentos anunciados. A proposta de localizar no Sul Fluminense um polo de desenvolvimento metalmecânico automotivo implicou em um esforço político que envolveu os governos estadual e municipal, contou com o apoio do Sindicato dos Metalúrgicos da Região Sul Fluminense (SMSF) ${ }^{3}$ e resultou na vinda, para os municípios de Resende e Porto Real, das empresas Volkswagen e PSA Peugeot Citroën (RAMALHO e SANTANA, 2002). A seleção das localidades contou com mecanismos de renúncia fiscal. A escolha de Resende para sediar a planta da VW, por exemplo, não foi uma decisão essencialmente técnica. 0 governo do estado do Rio de Janeiro contribuiu com uma parcela dos recursos (US\$ 15 milhões), disponibilizando condições de infraestrutura através da reativação da carteira do Fundo de Desenvolvimento Econômico e Social (FUNDES), coordenado pela Companhia Estadual de Desenvolvimento Industrial (CODIN); e o município, por sua vez, isentou o empreendimento de vários impostos (ABREU e RAMALHO, 2000, ABREU, BEYNON e RAMALHO, 2000).

No caso da primeira fábrica no Brasil da PSA Peugeot Citroën, idênticos mecanismos foram utilizados - doação de terras, isenções fiscais e condições de infraestrutura que atendiam aos interesses da montadora. Além de um empréstimo do BNDES, o próprio estado do Rio de Janeiro entrou como sócio, com cerca de 30\% de participação no montante de capital exigido para o empreendimento.

A implantação do polo automotivo no Sul Fluminense chamou também a atenção mundial em função da decisão da VW de instalar nele sua primeira e única planta de caminhões e de ousar no uso de uma experiência inovadora de organização da produção - a do “consórcio modular”. Desde o início, a unidade de Resende atraiu os olhos de especialistas da indústria por ter promovido uma mudança radical na noção de cadeias de fornecedores de autopeças, já que estes foram trazidos para dentro da fábrica como parceiros, deixando a VW de fora do processo de montagem dos veículos. (ABREU, BEYNON e RAMALHO, 2000, ARBIX e ZILBOVICIUS, 1997). Este modelo permanece, com vinte anos de existência,

3. Atual denominação do Sindicato dos Metalúrgicos de Volta Redonda, cuja denominação jurídica é Sindicato dos Trabalhadores nas Indústrias Metalúrgica, Mecânicas, de Material Elétrico, de Material Eletrônico e de Informática de Barra Mansa, Volta Redonda, Resende, Itatiaia, Quatis, Porto Real e Pinheiral. 
agora implementado pela MAN Latin America, montadora de caminhões do Grupo Volkswagen, que assumiu o controle da fábrica a partir de 2009.

\section{0 impacto regional}

0 balanço dos efeitos econômicos e sociais produzidos pela inserção do setor automotivo no Sul Fluminense (concentrado nos municípios de Resende, Porto Real e Itatiaia) tem mostrado que a região reativou e dinamizou a sua economia e conseguiu atrair novas empresas (além das montadoras), criar novos postos de trabalho e novas atividades de serviços, além de estimular a rearrumação e a formação de redes sociopolíticas locais.

0 trecho de notícia abaixo, de 2014, retirado de reportagem de um jornal regional, embora tenha um tom comemorativo, revela traços importantes da influência de uma das montadoras no município de Resende e na região.

A MAN Latin America, fabricante dos caminhões e ônibus Volkswagen e dos caminhões MAN, comemorou em $1^{\circ}$ de novembro 18 anos de fundação de sua fábrica, localizada em Resende. Em 1996, quando foi inaugurada, a planta contava com 200 empregados e produzia um caminhão por dia. Hoje, a empresa, que lidera o mercado de caminhões no Brasil, é a maior empregadora privada da cidade, com mais de cinco mil funcionários, e já ultrapassou a marca de 680 mil veículos produzidos. Ao longo de seus 18 anos na cidade, a empresa investiu largamente em suas instalações e produtos. Até 2017, o valor aplicado chegará a R 4 bilhões, contribuindo para o enriquecimento tecnológico da região e crescimento econômico. A fábrica revolucionou a economia de Resende, geran- do emprego e renda. A MAN Latin America é responsável hoje por 65\% da arrecadação de impostos do município [...]. (Fábrica de caminhões e ônibus completa dezoito anos, Diário do Vale, Volta Redonda, 03/11/2014).

0 montante da inversão de recursos trouxe, para os vários setores da sociedade regional e local, uma grande expectativa quanto aos efeitos positivos do crescimento da economia. Indistintamente, pequenos e médios empresários, políticos e agentes públicos, por um lado, e sindicatos e trabalhadores por outro, viram nesse contexto uma oportunidade não somente de vocacionar a região para a produção metalmecânica, considerando a já existente indústria siderúrgica e sua rede de fornecedores, mas também de criar de mais empregos qualificados e formalizados. A estrutura do mercado de trabalho se complexificou com as exigências das montadoras.

Durante os últimos vinte anos, essa expectativa oscilou em conjunturas econômicas favoráveis e desfavoráveis, dividindo opiniões quanto aos efeitos desse tipo de intervenção industrial e de projeto de desenvolvimento. No entanto, dados estatísticos recentes revelaram resultados positivos, como uma melhoria das condições de vida nos municípios envolvidos com a nova indústria e um crescimento dos empregos estáveis, embora os salários tenham permanecido mais baixos na comparação com o $\mathrm{ABC}$ paulista.

Para efeitos de análise, a questão que se coloca é avaliar se esta situação favorável pode ser entendida apenas como consequência direta do impulso econômico promovido pela vinda das grandes empresas, ou se este quadro se deve também ao avanço, de um modo geral, de políticas públicas estabelecidas ao longo dos anos 2000, em caráter municipal, estadual e federal. 


\section{Efeitos positivos}

A implantação da indústria automotiva elevou o emprego metalúrgico ao longo da década de 2000, dobrando o número de postos de trabalho nos municípios afetados pelo crescimento da atividade industrial.

Figura 1 - Evolução do emprego metalúrgico no Estado do Rio de Janeiro e no Sul Fluminense

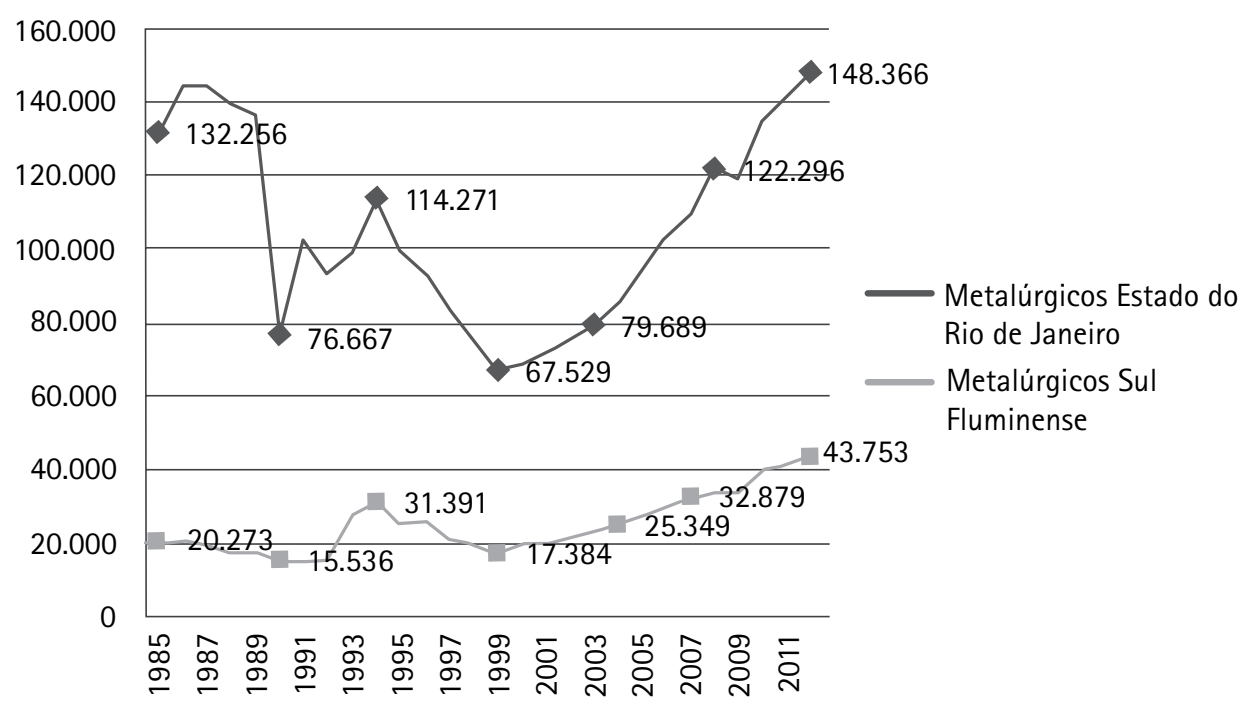

Fonte: Ministério do Trabalho e Emprego, RAIS-Estabelecimentos, anos selecionados.

Decompondo os números por subsetor de atividade econômica, percebe-se um salto substancial nos postos de trabalho do setor de "material de transporte", confirmando a interferência das montadoras no mercado de trabalho. 
Figura 2 - Número de metalúrgicos empregados em cada subsetor de atividade econômica do IBGE (Sul Fluminense, 1985 - 2012)

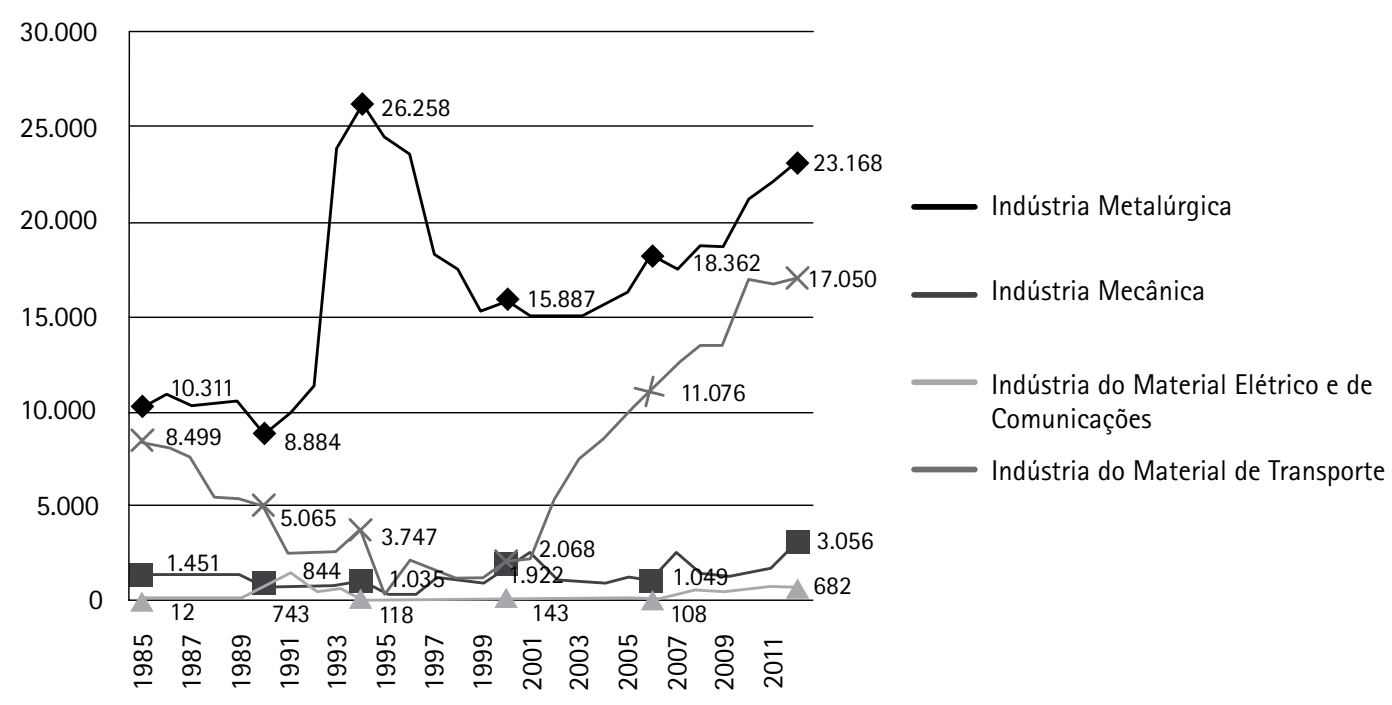

Fonte: Ministério do Trabalho e Emprego, RAIS-Vínculos, anos selecionados.

No que diz respeito às faixas salariais, respondentes a 1 a 3 salários mínimos (SM) os dados da Figura 3 mostram que houve e 3 a 5 SM. um crescimento substancial das faixas cor-

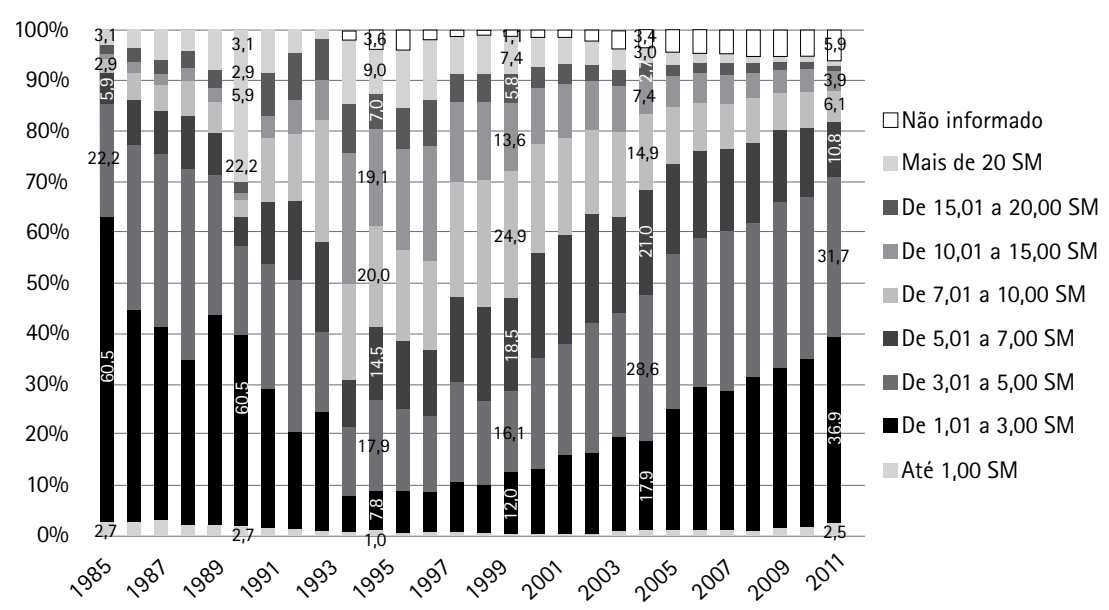

Fonte: Ministério do Trabalho e Emprego, RAIS-Vínculos, anos selecionados. 
Na Figura 4, os dados indicam que, ao longo dos anos 2000, os salários da indústria de "material de transporte" no Sul Fluminense em que se enquadra a indústria automotiva, permaneceram superiores aos da indústria metalúrgica em geral, com algumas oscilações no início da década em função da entrada em operação da fábrica da PSA Peugeot Citroën em 2001. Estes números, em conjunto com outros índices, revelam situações contraditórias nas quais a utilização de uma lógica empresarial voltada acima de tudo para otimizar os dividendos de seus acionistas, com um comprometimento com o território produtivo condicionado a vantagens fiscais, pode resultar em uma melhoria geral de índices benéficos à população das localidades atingidas.

Quando se fala de trabalho, estas contradições se agravam porque, ao mesmo tempo em que empregos formais na região apresentam salários acima da média do próprio setor no estado do Rio de Janeiro, os dados não se mantêm positivos quando comparados aos empregos e ao valor dos salários da principal região produtora de veículos do país ( $\mathrm{ABC}$ paulista), confirmando que o fator trabalho permanece como uma das principais justificativas para 0 deslocamento geográfico de investimentos. No caso da indústria automotiva brasileira, a geografia dos empregos exerce um papel essencial na lógica de acumulação estabelecida em cada região.

Figura 4 - Salário médio dos metalúrgicos segundo os subsetores de atividade econômica do IBGE (Sul Fluminense, valores em $R$ \$, referência 2012)

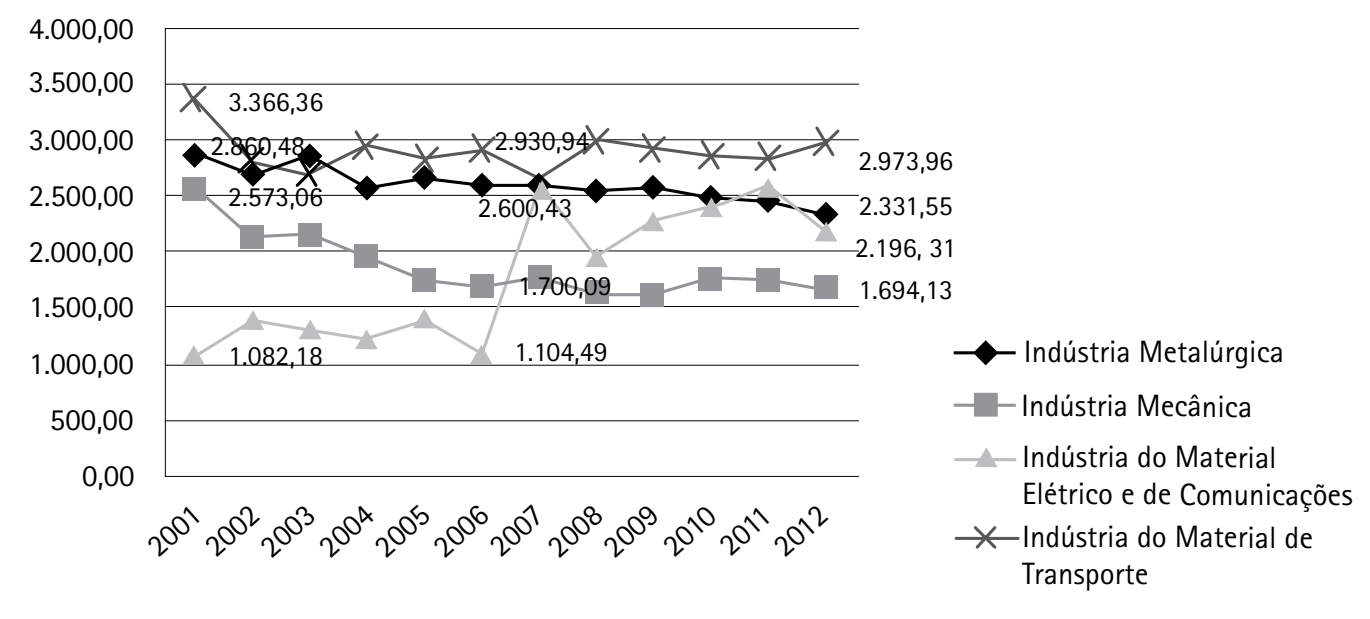

Fonte: Ministério do Trabalho e Emprego, RAIS-Vínculos, anos selecionados.

Outro efeito que pode ser considerado positivo, com relação direta ao tipo de exigência criado pelo recrutamento de funcionários das montadoras e de suas fornecedoras, se refere à escolaridade. A partir de 1996, quando a fábrica da VW começou a funcionar, os meta- lúrgicos apresentaram uma evolução positiva no nível de escolaridade, principalmente no que se refere ao ensino médio completo. Este nível específico de escolaridade corresponde às exigências de contratação exigidas pelas empresas do setor automotivo. 


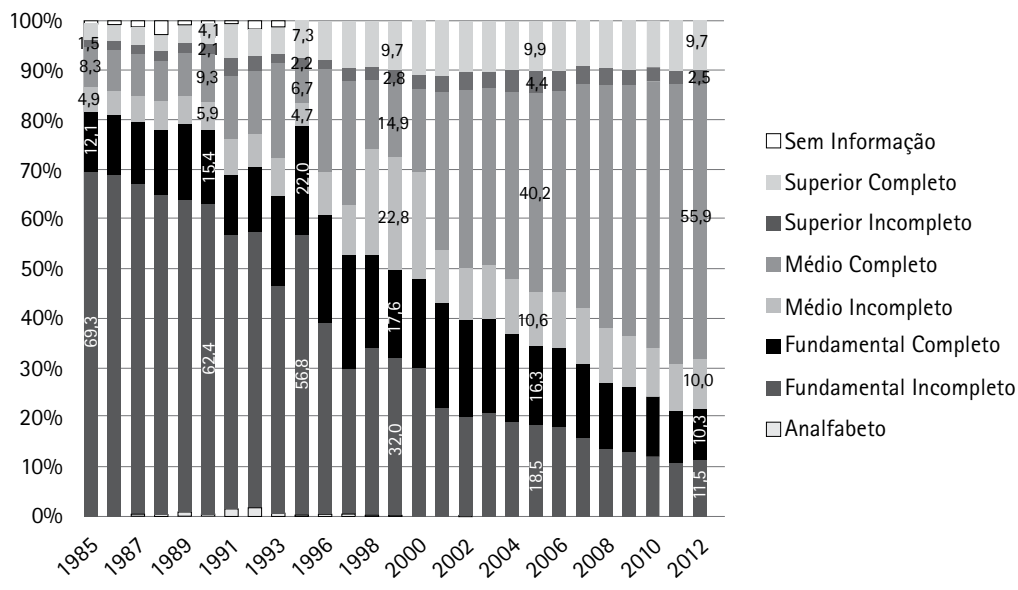

Fonte: Ministério do Trabalho e Emprego, RAIS-Vínculos, anos selecionados.

No que diz respeito ao tipo de vínculo empregatício dos metalúrgicos na região, os dados mostram um perfil de estabilidade, o que pode significar novamente o paradoxo de salários menores, mas com vínculo de emprego mais estável. Ao mesmo tempo, revelam um determinado número de meses de permanência no emprego que pode ser indicativo de postos de trabalho mais qua- lificados e menos sujeitos a estratégias de rotatividade. Ao longo dos anos 2000, com o crescimento da indústria automotiva, as empresas mantiveram certa longevidade nos empregos, embora, com a conjuntura econômica dos últimos anos, essa tendência tenda a se alterar pelas políticas de "lay -off' que têm sido utilizadas em momentos de crise econômica.

Figura 6 - Tipo de vínculo dos metalúrgicos empregados do Sul Fluminense (vínculo ativos no dia 31/12 de cada ano)

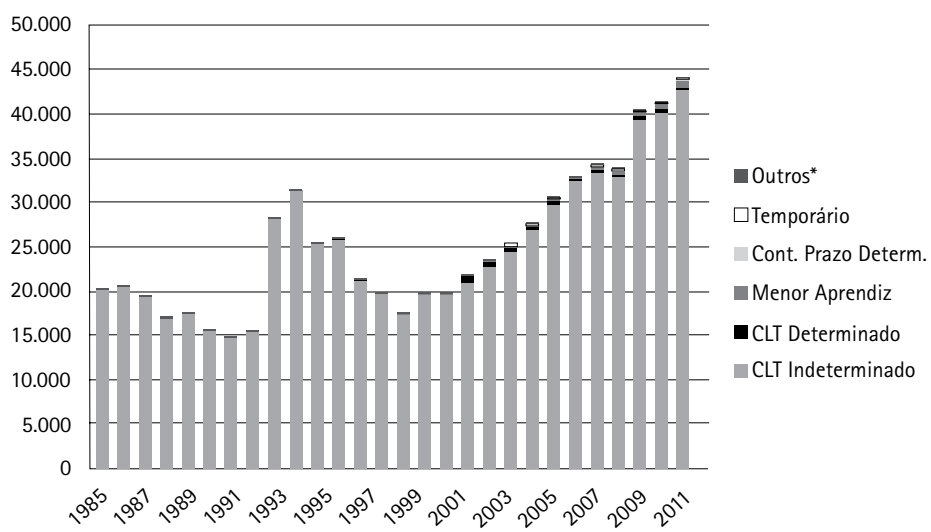

Fonte: Ministério do Trabalho e Emprego, RAIS-Vínculos, anos selecionados. 
Outros índices produzidos recentemente sobre os três municípios do Sul Fluminense mais relacionados com a indústria automotiva (Resende, Porto Real e Itatiaia) indicam uma evolução positiva no que diz respeito às condições gerais de vida dos seus habitantes. Na avaliação do Atlas de Desenvolvimento Humano do Brasil em 2013 (PNUD, IPEA e FJP, 2014), estas localidades se posicionam no estrato mais alto de qualidade de vida entre os municípios brasileiros.
No caso de Resende, entre 1991 e 2010, segundo o Atlas (PNUD, IPEA e FJP, 2014), o municipio "teve um incremento no seu IDHM de 37,14\%. [...] A distância entre o IDHM do município e o limite máximo do índice, que é 1, foi reduzido [sic] em 47,27\% entre 1991 e 2010". Abaixo, alguns sinais desse processo no que diz respeito a renda, longevidade e educação.

\section{Resende - IDHM}

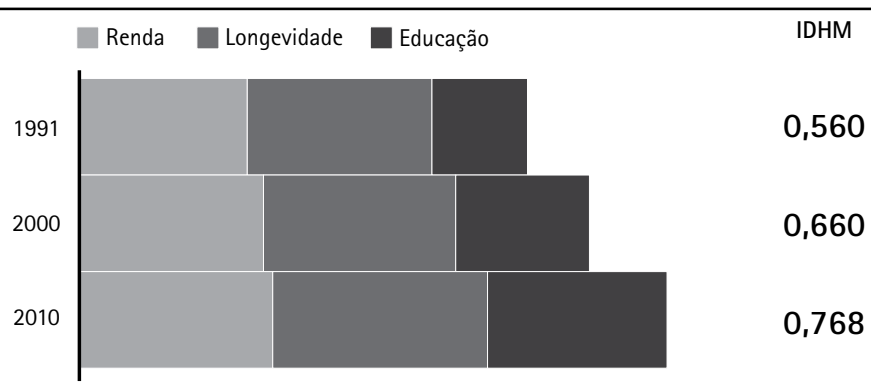

Porto Real também apresenta uma evolução positiva ao longo das duas últimas décadas. Segundo o Atlas (PNUD, IPEA e FJP, 2014), o município teve um incremento no seu IDHM de 60,22\%, [...] acima da média de crescimento nacional (47\%) e acima da média de crescimento estadual (32\%). [...] A distância entre o IDHM do município e o limite máximo do índice, que é 1 , foi reduzido em 48,29\% entre 1991 e 2010.

Porto Real - IDHM

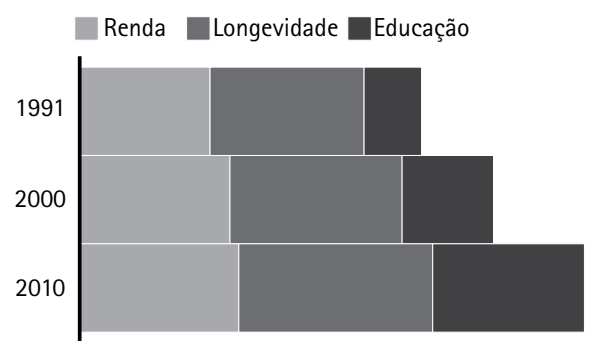

Evolução positiva também ocorre no terceiro município, Itatiaia, emancipado de Resende nos anos 1980. Nas duas últimas décadas, Itatiaia recebeu a Hyundai Heavy Industries e viu a Michelin Pneus ampliar suas instalações. Em 2014, começaram as obras de construção da fábrica da Land Rover no Brasil, transformando esse trio de municípios em portadores de grandes empresas ligadas ao setor automotivo. Segundo o Atlas (PNUD, IPEA e FJP, 2014), no que diz respeito ao IDHM, entre 1991 e 2010, Itatiaia teve 
um incremento de 43,66\%, abaixo da média de crescimento nacional (47\%) e acima da média de crescimento estadual (32\%), mas o hiato de desenvolvimento humano, ou seja, a distancia entre o IDHM do município e o limite máximo do índice, que é 1 , foi reduzido em 46,00\% entre 1991 e 2010.

\section{Itatiaia - IDHM}

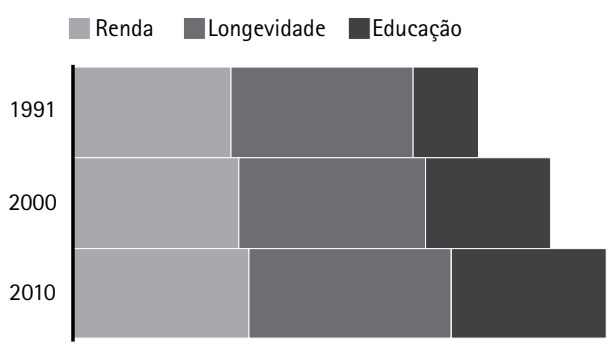

0,513

0,653

0,737

0 Índice Firjan de Desenvolvimento $\mathrm{Mu}$ nicipal (2011), também agregando dados sobre emprego e renda, educação e saúde, coloca o município de Resende como o de melhor índice no Rio de Janeiro e o de Porto Real em oitavo lugar no estado, embora ainda estejam distantes das primeiras posições no ranking nacional.

Índice FIRJAN de Desenvolvimento Municipal

\begin{tabular}{|c|c|c|c|c|c|c|c|}
\hline \multirow{2}{*}{\multicolumn{2}{|c|}{$\begin{array}{l}\text { Índice FIRJAN de } \\
\text { Desenvolvimento }\end{array}$}} & \multicolumn{2}{|l|}{ RJ } & IFDM & $\begin{array}{l}\text { Emprego e } \\
\text { Renda }\end{array}$ & Educação & Saúde \\
\hline & & \multicolumn{2}{|c|}{ IFDM BRASIL } & 0,7320 & 0,7219 & 0,7355 & 0,7387 \\
\hline \multirow{2}{*}{\multicolumn{2}{|c|}{ Municipal }} & \multicolumn{2}{|c|}{ Mediana dos Municípios } & 0,6781 & 0,5717 & 0,7525 & 0,7656 \\
\hline & & \multicolumn{2}{|c|}{ Máximo dos Municipios } & 0,8349 & 0,8271 & 0,8940 & 0,9313 \\
\hline \multicolumn{2}{|l|}{2011} & \multicolumn{2}{|c|}{ Mínimo dos Municípios } & 0,5164 & 0,2724 & 0,5572 & 0,4050 \\
\hline \multicolumn{2}{|c|}{ Ranking IFDM Geral } & & Município & IFDM & $\begin{array}{l}\text { Emprego e } \\
\text { Renda }\end{array}$ & Educação & Saúde \\
\hline $134^{\circ}$ & $1^{\circ}$ & RJ & Resende & 0,8349 & 0,8271 & 0,7990 & 0,8785 \\
\hline $138^{\circ}$ & $2^{\circ}$ & RJ & Volta Redonda & 0,8345 & 0,8213 & 0,8076 & 0,8745 \\
\hline $235^{\circ}$ & $3^{\circ}$ & RJ & Nova Friburgo & 0,8143 & 0,7568 & 0,8407 & 0,8453 \\
\hline $293^{\circ}$ & $4^{\circ}$ & & Rio de Janeiro & 0,8049 & 0,7718 & 0,8119 & 0,8311 \\
\hline $335^{\circ}$ & $5^{\circ}$ & $\mathrm{RJ}$ & Niterói & 0,7995 & 0,7888 & 0,7620 & 0,8476 \\
\hline $366^{\circ}$ & $6^{0}$ & & Angra dos Reis & 0,7967 & 0,7748 & 0,6890 & 0,9261 \\
\hline $372^{\circ}$ & $7^{\circ}$ & & Petrópolis & 0,7964 & 0,7727 & 0,7716 & 0,8448 \\
\hline $402^{\circ}$ & $8^{\circ}$ & $\mathrm{RJ}$ & Porto Real & 0,7934 & 0,7925 & 0,7180 & 0,8697 \\
\hline $416^{\circ}$ & $9^{\circ}$ & $\mathrm{RJ}$ & Rio das Ostras & 0,7909 & 0,7542 & 0,7586 & 0,8600 \\
\hline $420^{\circ}$ & $10^{\circ}$ & RJ & Macaé & 0,7905 & 0,7194 & 0,7821 & 0,8698 \\
\hline
\end{tabular}




\section{Crise de 2008 e os efeitos contraditórios}

0 estímulo à economia regional, ao longo da década de 2000, não poupou o Sul Fluminense dos prejuízos ocasionados pela crise financeira de 2008, quando a atividade industrial entrou em recessão e o corte de empregos se tornou uma realidade.

Os principais municípios do Sul Fluminense já tinham enfrentado crises econômicas em outras conjunturas, mas, no contexto de 2008/2009, a resposta regional teve novos desdobramentos. Destaca-se a criação do Fórum Demissão Zero, ainda em 2008, que reuniu atores políticos e econômicos com interesses diferenciados para discutir estratégias de ação coletiva com vistas a minorar os efeitos do desemprego e estabelecer canais de diálogo com grandes empresas e instâncias da administração pública estadual e federal (RAMALHO, 2012). Desse grupo diverso, estiveram à frente o Sindicato dos Metalúrgicos e a Igreja Católica, mas também participaram sindicatos e associações patronais, representantes da indústria e do comércio, movimentos sociais e membros qualificados da administração pública municipal (incluindo prefeitos e secretários municipais).

0 desempenho mais importante de contestação à demissão como estratégia das grandes empresas diante da crise, coube ao Sindicato dos Metalúrgicos do Sul Fluminense. Esta entidade, embora tendo que se defrontar ao longo dos anos 1990 e 2000 com uma realidade fabril alterada pela implantação de relações de trabalho flexíveis na cadeia produtiva regional e novos desafios de representação, tendo em vista o crescimento substancial do opera- riado industrial automotivo (RAMALHO, 2005), preservou recursos políticos obtidos nas práticas de negociação com a CSN, em Volta Redonda ${ }^{4}$, e agregou novas práticas com sua militância na Volkswagen (VW) e na PSA Peugeot Citroën, o que lhe permitiu assegurar a legitimidade de seus pleitos.

Também a participação dos representantes do poder público (prefeitos, secretários municipais, vereadores, deputados estaduais e federais) foi expressiva. Divergências partidárias foram secundárias naquela conjuntura, frente à urgência das demandas sociais, e os políticos não se furtaram a atuar conjuntamente em busca de estratégias para que as empresas superassem a crise e criassem novos empregos e, ao mesmo tempo, de pressionar os governos estadual e federal pela realização de obras consideradas essenciais para o desenvolvimento econômico regional. Foi encaminhada uma proposta bastante criativa, tanto no que diz respeito a compras de veículos, como com relação a planos mais ambiciosos de renovação de frota (de caminhões).

Lideranças políticas, como prefeitos da região Sul Fluminense, estarão hoje, às 8 horas, na montadora Peugeot Citroën, em Porto Real. Às 10 horas, eles estarão com a direção da montadora de Ônibus e Caminhões da Volkswagen, localizada no Polo Industrial de Resende. Durante o encontro, será apresentada às empresas a proposta de compra ou aluguel de veículos a preços mais acessiveis para as prefeituras da região $(A$ Voz da Cidade, Volta Redonda, 04/02/2009).

Este tipo de iniciativa sensibilizou também alguns representantes dos trabalhado-

4. Para uma descrição mais detalhada desse período da história do sindicato ver PEREIRA, 2007; GRACIOLLI, 1997 e 2007; DIAS, 2010. 
res que viram nas negociações uma possibilidade de estancar o desemprego.

Tivemos um evento lá dentro da Volks e já existe um projeto de renovação das

frotas [...], A empresa faz o caminhão mais barato, o governo federal, estadual e municipal abre mão de algum percentual do imposto. 0 sindicato pode também ajudar [...]. Então isso aí é importante para você gerar riqueza, poder gerar emprego. Nós fomos a Brasília, e entregamos ao ministro (Renato Soares, presidente do sindicato dos metalúrgicos de Volta Redonda, entrevista ao autor, 20/03/2009).

Por outro lado, esse espaço de discussão pública foi também usado pelos trabalhadores para questionar o corte de empregos proposto pelas grandes empresas como forma de debelar a crise. Foi o que ocorreu com a PSA Peugeot-Citroën:

O Sindicato dos Metalúrgicos do Sul Fluminense vai aproveitar o encontro com o ministro do Trabalho, Carlos Lupi, [...] no Rio de Janeiro, [para] debater as demissões na Companhia Siderúrgica Nacional (CSN) e também denunciar as demissões que estão ocorrendo na montadora PSA Peugeot Citroën, localizada em Porto Real [...] (Sindicato vai denunciar demissões a Lupi - Sindicato dos Metalúrgicos aproveitará reunião para denunciar demissões em montadoras, Voz da Cidade, Volta Redonda, 05/02/2009).

A VW apelou para o uso dos recursos do Fundo de Amparo ao Trabalhador (FAT), o que garantiu 700 operários em casa, recebendo menos, mas sem perda do posto de trabalho. 0 sindicato se contentou com essa alternativa diante das circunstâncias e o uso do recurso público parece não ter suscitado nenhuma dúvida quanto à legitimidade desta solução.

Nesse momento de crise, a Volkswagen tem 700 funcionários mantidos pelo FAT, Fundo de Amparo ao Trabalhador. Até teve uma negociação e eu acho que a comissão de fábrica atual deu mole, porque arrumaram um abono de R\$ $1.800,00$ para o trabalhador e não arrumaram $\mathrm{R} \$ 1.800,00$ para o pessoal que está no FAT (Vereador Mirim, da Câmara Municipal de Resende e Ex-membro da Comissão de Fábrica da VW de Resende, em entrevista ao autor, 16/04/2009).

0 Fórum Demissão Zero, independentemente de sua continuidade, pode ser visto como um exemplo para aprofundar uma reflexão sobre experiências regionais de ação coletiva e iniciativas de institucionalização e cooperação entre atores sociais diversos, em contextos de localidades dependentes de grandes empresas.

No contexto de reconfiguração industrial, também se colocou a possibilidade de empresas que fazem parte de "redes globais de produção" se envolverem em dinâmicas que alterem o perfil empresarial já consolidado da região, promovendo uma integração em algum nível da cadeia produtiva, com desdobramentos virtuosos para as pequenas e médias empresas e para o emprego. A criação do "APL Metal-Mecânico" do Sul Fluminense, composto por Metalsul, Firjan, Sebrae e pela Secretaria de Desenvolvimento Econômico, Energia, Indústria e Serviços do Estado do Rio de Janeiro, segundo Monteiro e Lima (2015), teria sido uma resposta regional ao crescimento das atividades industriais, com a vinda da cadeia automotiva, embora ainda tendo como referência o complexo siderúrgico centralizado na Companhia Siderúrgica Nacional (CSN). 
A prefeitura, através da Secretaria de Trabalho e Renda, participou na última terça-feira (11), do Workshop Parcerias Estratégicas, desenvolvido pelo Cluster Automotivo do Sul Fluminense, realizado no auditório da Firjan (Federação das Indústrias do Estado do Rio de Janeiro) de Resende, no bairro Jardim Jalisco. [...] 0 Cluster Automotivo reúne as empresas AKC Aethra, Benteler, BMB, Carese, Continental, CSN Galvasud, Faurecia, MAN Latin America, MA Automotive, Maxion, Meritor, Michelin, Nissan, Powertrain, PSA Peugeot-Citroën, Remon e Suspensys. 0 setor representa cerca de 15 mil empregos diretos e outros 30 mil indiretos (Resende participa de reunião do cluster automotivo, Diário do Vale, Volta Redonda,13/11/2014).

Nesse aspecto, porém, a expectativa por mais colaboração e integração produtiva entre empresas não ocorreu. Em texto recente, Monteiro e Lima (2015) argumentam que, nos últimos vinte anos, por decisão das próprias montadoras, a mobilização e integração dos empresários locais na lista de fornecedores não se efetivou substantivamente. ${ }^{5}$

0 arrefecimento da economia brasileira nos últimos três anos tem trazido mudanças no quadro positivo de empregos que se consolidou ao longo da década de 2000 na região. 0 desemprego passou a fazer parte do cotidiano dos operários do setor automotivo e as empresas passaram a medir as suas estratégias de recrutamento a partir das oscilações do mercado. No Sul Fluminense, a produção das duas principais montadoras, PSA Peugeot Citroën e
MAN-VW, sofreu com a queda de vendas e seus desdobramentos sobre o mercado de trabalho. Na atual conjuntura, a dispensa de trabalhadores atingiu a região, especialmente através do sistema de "lay-off", no qual os operários esperam o retorno ao trabalho com recursos subsidiados pelo Fundo de Amparo ao Trabalhador (FAT).

No caso da PSA Peugeot Citroën:

A demissão ou a colocação de trabalhadores em lay-off pela indústria de material de transporte (montadoras e autopeças, principalmente) já afeta o emprego formal em outros setores das cidades-polo desse setor. [...] Proporcionalmente, é a pequena Porto Real, localizada no Sul Fluminense, que enfrenta a pior situação. As demissões totais somam 2.109 vagas (1.517 na indústria de transporte e 592 nos demais segmentos da economia local), o que representa, de acordo com os dados do Caged, 18,5\% do emprego formal na cidade. [...] A cidade é sede da Peugeot, que colocou 650 funcionários em lay-off em fevereiro e depois adotou um programa de demissão voluntária [...] (Nas cidades-polo do setor automotivo, desemprego já atinge outros setores, Valor Econômico, São Paulo, 16/10/2014).

No caso da MAN-VW:

A MAN, montadora que disputa com a Mercedes-Benz a liderança do mercado de caminhões, vai dar férias coletivas e parar a produção por mais três semanas entre junho e julho. [...] Em abril, chegou a paralisar a fá-

5. Para esses autores (2015, p. 2), no caso do Sul Fluminense, é necessário considerar limites estruturais no que diz respeito "a interação entre os aglomerados locais e as cadeias globais" e na distribuição de "poder entre os diferentes elos destas cadeias". Ressaltam que "a adoção de estratégias baseadas em cooperação e afıns não ocorre em vácuos históricos e culturais, ou seja, é preciso levar em consideração os legados, os recursos institucionais e elementos cognitivos que organizam as regiões”. 
brica por uma semana inteira. Para administrar o excesso de mão de obra, 200 operários foram afastados temporariamente da produção em regime de lay-off, no qual contratos de trabalho são suspensos por até cinco meses. [...] (MAN volta a parar produção no RJ, Valor Econômico, São Paulo, 09/08/2014).

A redução de vendas no mercado automotivo afetou também as negociações salariais e colocou o Sindicato dos Metalúrgicos na defensiva. A estratégia do Sindicato tem sido especialmente no sentido da manutenção dos empregos, ainda que com redução salarial:

Resende e Porto Real devem conviver, nos próximos meses, com redução ou estagnação no número de postos de trabalho das montadoras que funcionam as duas cidades. Os trabalhadores serão afetados, também, por acordos coletivos menos vantajosos do que em anos anteriores. A PSA Peugeot Citroën, de Porto Real, propôs na semana passada 5\% de reajuste (abaixo do INPC), sem antecipação da PLR, com cortes nos valores de horas extras e noturnas e suspensão temporária do ticket alimentação [...] (Salário do setor automotivo subirá menos, Diário do Vale, Volta Redonda, 31/05/2014).

Os empregados do Consórcio Modular da MAN Latin America aprovaram ontem, por grande maioria, segundo o Sindicato dos Metalúrgicos do Sul Fluminense, a proposta das empresas do Consórcio Modular - que reúne a própria MAN e diversos de seus principais fornecedores - para a adoção de medidas de contenção de custos. [...] 0 presidente do sindicato, Silvio Campos, acrescentou que sua expectativa é que o Consórcio Modular tenha, ao fim de 2015, um número de empregados igual ou superior ao que possui atualmente: '[...]Conseguimos manter o nível de empregabilidade na MAN' [...] (Demissões voluntárias na MAN Latin America começam amanhã, Diário do Vale, Volta Redonda, 10/12/2014).

Até mesmo a Nissan, recentemente inaugurada (2014), já iniciou a produção de veículos suspendendo contratos de trabalho e aumentando a perspectiva do desemprego na região. As crises econômicas anteriores atingiram principalmente o emprego no setor siderúrgico, pela presença da CSN em Volta Redonda. Na atual conjuntura, pela primeira vez, esta situação se coloca para o mercado de trabalho da indústria automotiva.

A Nissan vai suspender por até cinco meses os contratos de trabalho de 279 funcionários da fábrica de Resende, no sul do Rio de Janeiro. 0 "layoff", como é conhecida essa ferramenta de afastamento de operários, atinge 15\% dos 1,8 mil empregados da fábrica, inaugurada há menos de cinco meses. (Nissan afasta operários em Resende, Valor Econômico, São Paulo, 11/09/2014).

\section{A vantagem do trabalho barato}

Uma avaliação da reconversão do Sul Fluminense em um território produtivo marcado por atividades econômicas promovidas pela indústria automotiva demonstra que a questão do trabalho e do emprego permanece essencial tanto para a estratégia das empresas em busca de localidades com vantagens comparativas, quanto para as expectativas de emprego formal alimentadas pelos operários e pela organização sindical.

A procura de localidades com salários baixos e sindicatos fracos foi característica do processo de reespacialização da in- 
dústria automotiva brasileira, em meados dos anos 1990. No Sul Fluminense, após vinte anos, este traço marcante se manteve talvez como a principal vantagem consolidada pelas empresas em comparação com outras regiões industriais; mas os efeitos da globalização econômica e da presença de empresas componentes de "redes globais de produção" sobre o trabalho na região se manifestaram também a partir da introdução de uma estrutura produtiva flexibilizada, enxuta, com a articulação das firmas em rede. Desde o início, os operários contratados foram instruídos para esse perfil.

Contudo, para a força de trabalho local, a vinda das montadoras significou também uma oportunidade de se valorizar no mercado local, pela qualificação profissional (graças à formação obtida no Senai), pela possibilidade de um vínculo empregatício formalizado e pela legitimidade conferida a um posto de trabalho exercido em empresas multinacionais.

No que diz respeito aos salários, devese considerar que, apesar de os valores locais estarem abaixo dos praticados por esse mesmo setor industrial no ABC paulista, ainda são iguais ou melhores do que os salários médios regionais e locais em outras áreas de atuação. A permanência desta defasagem continua a causar dificuldades adicionais para a ação sindical que não conseguiu, ao longo desses anos, equiparar os salários regionais aos valores de outros municípios industrializados.
Vantagem competitiva em custos com mão de obra sempre foi uma das principais razões para o deslocamento da indústria automotiva para novas regiões e, no que pode ser considerada uma segunda fase do "regime automotivo" brasileiro, que vem ocorrendo nestes últimos anos, esta estratégia permanece como elemento essencial para a decisão de implantar outras fábricas em locais variados do Brasil e também em municípios no Sul Fluminense.

0 Dieese, com o apoio do sindicato dos metalúrgicos do $\mathrm{ABC}$, realizou - pela primeira vez em 2003, e em uma nova rodada em 2007 - um levantamento de preços e salários nos municípios com a presença de montadoras, coletando mais de cinco mil respostas, em 470 pontos comerciais. Os resultados mostraram que se por um lado, ao longo dos anos 2000, grandes diferenças de remuneração permaneceram entre os municípios, por outro houve também, na maioria dos casos, uma convergência de valores de preços e serviços.

No último levantamento realizado pelo Dieese, em 2007, comparações entre o Sul Fluminense e o ABC paulista (como exemplo da região mais tradicional e com melhores salários) demonstraram que, mesmo com o passar dos anos, a desvantagem salarial do Sul Fluminense não recuou. Na tabela 1, seja por hora ou pelo valor total, a remuneração dos trabalhadores horistas (i.e do chão de fábrica) do Sul Fluminense não atinge nem a metade daquela de seus colegas em São Paulo. 
Tabela 1 - Remuneração nas empresas montadoras de veículos, por município, Brasil, 2005 (Em reais) e (ABC=100)

\begin{tabular}{lll}
\hline Municipios & Horistas-Diretos (em reais/ mensal) & Salário Hora (em reais) \\
ABC - SP & $3.563,22$ & 20,49 \\
Resende - RJ & $1.396,65$ & 7,30 \\
Porto Real - RJ & $1.096,56$ & 6,0 \\
& & \\
\hline
\end{tabular}

Fonte: RAIS/2005 - Ministério do Trabalho e Emprego (MTE). Tabela extraída de Dieese-ABC - Do Salário às Compras, 2007.

Em termos de tempo de trabalho utilizado para adquirir a cesta de produtos e serviços, os dados do Dieese (2007) demostram que um operário no Sul Fluminense tem que trabalhar por muito mais tempo para adquirir a mesmo conjunto de itens.

Tabela 2 - Gasto Médio para a aquisição de cesta de produtos e serviços, por municípios com montadoras e comparação com salário médio dos trabalhadores da produção, Brasil, 2007

\begin{tabular}{lllll}
\hline Cidade & $\begin{array}{l}\text { Remuneração } \\
\text { (em reais/ mensal) }\end{array}$ & $\begin{array}{l}\text { Despesa Total } \\
\text { (em reais/ mensal) }\end{array}$ & $\begin{array}{l}\text { Salário necessário para a } \\
\text { aquisição da cesta } \\
\text { (em salários médios) }\end{array}$ & $\begin{array}{l}\text { Saldo } \\
\text { Salário } \\
\text { Mensal (\%) }\end{array}$ \\
ABC - SP & $3.563,22$ & $2.554,28$ & 0,72 & 28 \\
Resende - RJ & $1.396,65$ & $2.367,61$ & 1,70 & -70 \\
Porto Real - RJ & $1.096,56$ & $2.266,04$ & 2,07 & -107 \\
\hline
\end{tabular}

Fonte: Dieese-ABC - Do Salário às Compras, 2007.

Tomando-se a média salarial dos metalúrgicos de todo o Brasil de 2001 a 2012, selecionando-se as regiões e os estados em comparação - Rio de Janeiro e São Paulo - (Figura 7), os dados demonstram também que, com todas as expectativas criadas quanto aos empregos fornecidos pelas montadoras para o Sul Fluminense, o quesito salarial confirma ser uma vantagem comparativa permanente para as empresas, que não se alterou ao longo da década. Permanece uma média salarial não só bastante inferior à do $\mathrm{ABC}$ paulista, como também abaixo das médias do país e do estado do Rio de Janeiro. 
Figura 7 - *Médias calculadas a partir do valor nominal da remuneração obtida pelos trabalhadores no mês de dezembro de cada ano. Valores atualizados para o ano de 2012 a partir do IPCA/IBGE.

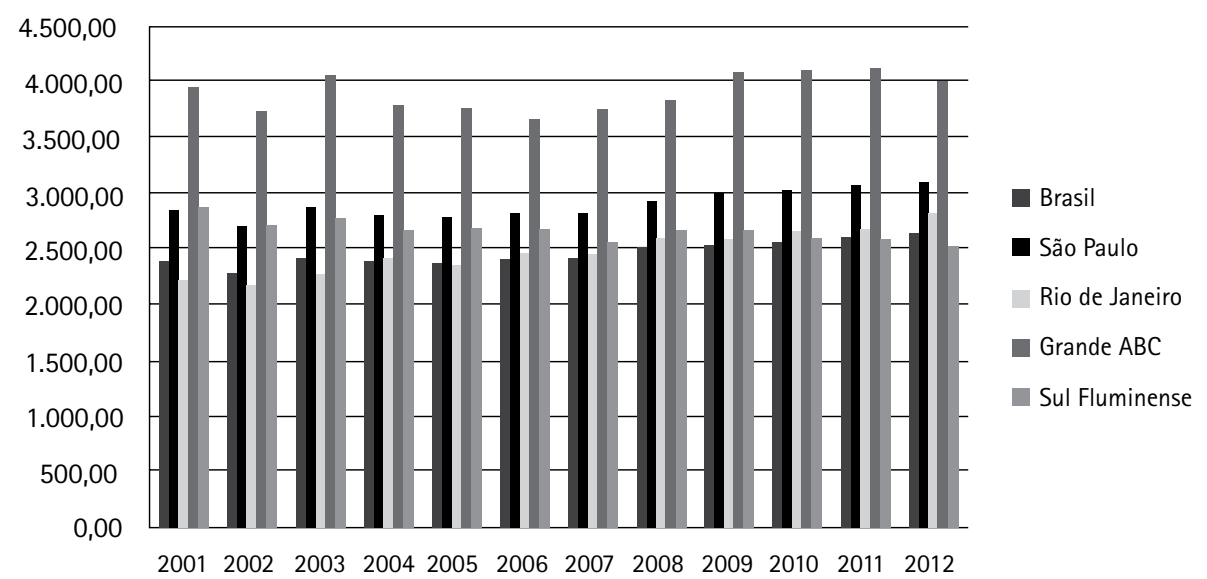

Fonte: Ministério do Trabalho e Emprego, RAIS-Vínculos, anos selecionados.

0 fator trabalho permanece como essencial para a decisão de novos investimentos deste setor industrial mesmo em uma conjuntura de pouco crescimento econômico como aquela posterior a 2010. Nesse contexto, a estratégia de preservar os postos de trabalho, acima de tudo, também fragiliza a atuação do Sindicato dos Metalúrgicos. O Sindicato se vê instado a apoiar novos investimentos e novas fábricas mesmo enfrentando estas desvantagens insuperáveis.

0 presidente do Sindicato dos metalúrgicos, Renato Soares, participou da inauguração da fábrica da Nissan. 0 evento, que aconteceu na terça feira (15), em Resende, foi bastante aplaudido pelos trabalhadores já que deverá gerar em torno de dois mil novos empregos na região, já que a empresa já atraiu dez fornecedores. A fábrica de Resende é a segunda da Nissan no Brasil. A primeira planta instalada é a do Paraná [...] e a de Resende, que teve um custo de $\mathrm{R} \$ 2,6$ bilhões, deverá pro- duzir 200 mil automóveis por ano (Sindicato prestigia inauguração da planta da Nissan em Resende. Boletim 9 de Novembro, Volta Redonda, 25/04/2014).

Com a situação do mercado e sem perspectivas de melhora para os próximos meses, o sindicato vem negociando com as empresas alternativas que garantam o nivel de empregabilidade na região. Aqui na MAN, como não chegou ao extremo de ter que parar um turno de produção, como ocorreu em 2012 com o terceiro turno, o sindicato conseguiu com a empresa a opção de desligamento com uma compensação financeira, além do pagamento das verbas rescisórias - PDV (Suspensão de contrato na MAN ou PDV, Boletim 9 de Novembro, Volta Redonda, 07/04/2014).

Esta é certamente uma das principais razões pelas quais as empresas continuam investindo na região Sul Fluminense e em outras regiões do país. 
Onze meses depois do anúncio oficial do projeto, a Jaguar Land Rover deu o pontapé inicial nas obras da fábrica de $\mathrm{R} \$ 750 \mathrm{mi}$ lhões que será erguida pela montadora britânica em Itatiaia, no sul do Rio de Janeiro. (Jaguar Land Rover começa obras no Rio, Valor Econômico, São Paulo, 25/10/2014).

0 presidente mundial da Nissan-Renault, o franco-brasileiro Carlos Ghosn, disse ontem que, independentemente da atual retração do mercado brasileiro de automóveis, a Nissan começará este mês a produzir na fábrica de Resende (RJ) um novo motor para carro popular, de três cilindros e 1,0 litro. A montadora vai investir R 100 milhões dentro do plano que prevê aplicação de $\mathrm{R}$ 2,6 bilhões no período 2013-2016. [...] Ghosn, que nasceu em Roraima mas desde cedo estudou na França, disse que a empresa manterá o plano de investimentos de $\mathrm{R} \$ 2,6$ bilhões para o período 2013-2016, independentemente da conjuntura atual do mercado de automóveis no Brasil, que mostra queda nas vendas. (Nissan produzirá novo motor no Rio, Valor Econômico, São Paulo, 07/01/2015).

Além do fator trabalho, constata-se também a manutenção de uma política de incentivos e isenções fiscais, repetindo os anos 1990, como forma de estimular e dar a continuidade aos projetos empresariais.

A fabricante de caminhões MAN Latin America será enquadrada no Programa de Atração de Investimentos Estruturantes (RioInvest), o que tornará possível o uso do Fundo de Desenvolvimento Econômico e Social (Fundes) para o projeto de expansão do parque industrial da empresa, em Resende. Isto é o que prevê o projeto de lei 3.093/14, do Poder Executivo, que a Assembleia Legislativa do Rio (Alerj) aprovou esta semana, em discussão única. Pelo texto votado, o financiamento firmado entre o estado e a montadora terá limite de crédito da ordem de $\mathrm{R} \$$ 2,1 bilhões. [...] A MAN também terá regime tributário especial em relação ao ICMS, que se daria nas ações aduaneiras e no pagamento do imposto incidente. 0 regime atingiria a aquisição de equipamentos, peças, matéria -prima e prestação de serviços, entre outros itens. [...] 0 benefício será concedido por 50 anos, sendo prorrogáveis por mais 50 , desde que com estudo de viabilidade econômica e financeira devidamente justificado. [...] "Esse regime tributário já foi concedido à Jaguar e à Nissan. A MAN quer ampliar sua produção. Esse tipo de política tributária arrojada vai ampliar nosso parque industrial”, avaliou (o secretário de Estado da Casa Civil, Leonardo) Espínola. (Governo estadual concede benefícios à MAN Latin America, Diário do Vale, Volta Redonda, 6/12/2014).

0 poder de pressão desse setor da indústria, comandado por empresas multinacionais, fica patente nas palavras ousadas e desafiadoras do presidente da MAN, instalada em Resende. A cobrança está relacionada à situação da economia brasileira e à política econômica do governo e o argumento principal da crítica se manifesta na ameaça de desemprego.

A recuperação da indústria brasileira depende da agilidade da presidente Dilma Rousseff na defınição de novas políticas econômicas já para 2015. Essa é a avaliação de Roberto Cortes, presidente da MAN, fabricante de caminhões e ônibus da marca Volkswagen em Resende, no sul do Rio de Janeiro. [...] 0 presidente da MAN vê com bons olhos políticas que preservem o controle da inflação, o superávit primário e o câmbio flutuante conduzido pelos últimos governos. [...] Cortes ex- 
plica que a definição sobre o futuro dos trabalhadores em "layoff" vai depender, basicamente, de quatro variáveis: de quanto será o nível da atividade econômica; da retomada da confiança do consumidor; de estímulos para o setor industrial, como a manutenção do Programa de Sustentação do Investimento (PSI), do BNDES; e de como se dará a recuperação dos principais mercados importadores. (MAN pede agilidade do governo, $\mathrm{Va}$ lor Econômico, São Paulo, 07/11/2014).

Segue a mesma linha o Presidente da Nissan, ao criticar o estado geral da economia brasileira exigindo melhores condições ao país e ao seu governo.

A necessidade de o governo restaurar as contas públicas para não ter notas de crédito rebaixadas por agências de classificação de risco fecha portas a incentivos ao consumo de automóveis no ano que vem, avalia o presidente da Nissan no país, François Dossa. [...] "O IPI vai subir. 0 Brasil não tem nem escolha. 0 país não pode perder o grau de investimento e, por isso, terá de mostrar maior rigor fiscal", afırma o executivo. "Perder o grau de investimento é pior do que uma nova queda no consumo de carros. Entre os dois males, o governo prefere escolher esse [o impacto nas vendas de veículos]", acrescenta Dossa, que chegou à Nissan após uma carreira construída no mercado financeiro - antes de assumir o comando da montadora, foi presidente do banco francês Société Générale no país. (Para Nissan, IPI dos carros terá de subir, Valor Econômico, São Paulo, 08/12/2014).

\section{Considerações Finais}

Uma discussão sobre a capacidade de interferência de empresas que fazem parte de "redes globais de produção" em pro- cessos de desenvolvimento regional e seus impactos sobre localidades pode revelar um complexo conjunto de motivações e interesses associados a esses territórios produtivos, problematizando qualquer análise unilateral sobre esses processos. Tratar a "reinvenção" do Sul Fluminense apenas como alvo imóvel de estratégias globais de acumulação das empresas em busca de vantagens para os seus acionistas não é suficiente para explicar exemplos concretos de melhoria geral de vida, de criação e manutenção de um mercado de trabalho com profissionais mais escolarizados e qualificados e de aumento nas atividades econômicas e na arrecadação de impostos por parte dos órgãos públicos.

Como tratar esta constatação que beira um paradoxo? Os dados apresentados neste texto podem ajudar nos exercícios de identificar e discutir os variados interesses de grupo sociais envolvidos nesse processo e de aprofundar a compreensão de um processo, que não é uma via de mão única, e que depende de conjunturas econômicas globais, nacionais e regionais e do desempenho político de diversos atores envolvidos em uma arena de disputa de poder nos mais variados níveis.

Nesse sentido, no Sul Fluminense, por um lado:

a) A implantação da indústria automotiva confirma estratégias globais das empresas, no sentido de buscar permanentemente vantagens comparativas com outras regiões, principalmente através da oferta de incentivos fiscais e de mão de obra barata.

b) 0 estabelecimento de laços estáveis com fornecedores de terceiro nível na região não ocorreu na dimensão esperada. As pequenas e médias empresas do Sul Fluminense têm uma história de colabo- 
ração com o setor siderúrgico através da CSN, em Volta Redonda, mas esta articulação não se transferiu automaticamente para a indústria automotiva. A criação de um “APL Metalmecânico" foi uma tentativa estimulada pelos governos estadual e municipal e por associações empresariais regionais de se adaptar às novas demandas dessa nova rede de produção. A avaliação, depois de duas décadas, não permite considerar esta iniciativa como bem-sucedida, tendo em vista que as multinacionais se apoiaram em um tipo de fornecedor de primeiro nível que ora trazia sua produção de fora da região, ora se organizava em torno das fábricas na produção de sistemas prontos para entrar na linha de montagem.

c) Os agentes públicos regionais e estaduais continuaram a oferecer condições favoráveis como forma de atrair novos investimentos industriais, mantendo uma concepção de desenvolvimento dependente das estratégias globais das empresas e que tem como base incentivos econômicos e fiscais vindos de recursos públicos, com o argumento da criação de mais empregos.

Por outro lado, existe o cenário onde:

d) A consolidação da indústria automotiva ao longo das duas décadas foi fator estimulador da formação de uma mão de obra escolarizada e com razoável grau de qualificação. Este quadro favorável se deve ao apoio concedido pelo Senai e a iniciativas de formação das próprias empresas. 0 Sul Fluminense atraiu também instituições de formação universitária, algumas dedicadas a atividades da indústria, que incorporam cada vez mais alunos trabalhadores.

e) A criação de mais ofertas de emprego formal mudou o perfil do mercado de trabalho local e regional. Consolidou-se uma classe operária com regularidade salarial, o que fez ampliar o mercado de habitações, os créditos comercial e bancário e a possibilidade de utilizar estas formas de reconhecimento como trabalhador e cidadão para constituir uma identidade própria.

f) 0 fato de o setor automotivo ter sido afetado pela crise mundial de 2008 criou oportunidades para novas articulações políticas (incluindo sindicatos e movimentos sociais) e empresariais ao nível regional, com consequências benéficas à mobilização social pelo emprego e à pressão para o enraizamento e o compromisso das empresas com as localidades.

Ao mesmo tempo, contata-se que:

g) Após quase vinte anos da constituição de uma classe operária diferenciada, o Sindicato dos Metalúrgicos da Região Sul Fluminense ainda luta para organizar os diferentes tipos de reivindicação e tradições incorporadas nos setores representados - siderúrgico e automotivo. Com a tradição de tratar dos problemas de uma siderúrgica em um espaço urbano com histórico de dependência da empresa, o Sindicato dos Metalúrgicos tem tido dificuldades de melhor representar os trabalhadores que estão empregados nas montadoras, com uma dinâmica de trabalho própria e laços internacionais. 0 resultado desse processo tem sido a multiplicação de conflitos político-institucionais entre sindicalistas dos diferentes perfis, com o surgimento de uma recente proposta de desvincular a representação dos trabalhadores desses dois setores industriais.

h) 0 fator trabalho, no caso do Sul Fluminense, se confirmou como elemento fundamental para a consolidação 
desse tipo de empresa, tendo em vista a possibilidade de acionar o emprego e o desemprego como moeda de troca dentro das fábricas. Distinguindo as fábricas instaladas em regiões greenfield daquelas "maturadas" (brownfields), Martin (2001, p. 391-392), considera que as plantas novas, ditas "interioranas”, surgem flexíveis e encontram uma fraca representação sindical. Para este autor, as empresas se aproveitam da "tabula rasa" social e com isso "podem escolher seletivamente os operários, executar práticas de recursos humanos impensáveis nas fábricas mais antigas [...]".

i) Por fim, pode-se dizer que o preço baixo do trabalho, um dos principais fatores para justificar a fuga do $\mathrm{ABC}$ paulista e o deslocamento, nos anos 1990, para outras regiões do Brasil como o Sul Fluminense, se mantém inalterado na equação que compõe o processo de acumulação dessas empresas ao longo das últimas duas décadas. Na primeira geração e agora na segunda geração de empresas do setor automotivo implantadas, a busca por pagar salários baixos permanece como ponto central de suas estratégias.

\section{Referências}

ABREU, A.; BEYNON, H.; RAMALHO, J.R. (2000), The Dream Factory: VW's Modular System in Resende, Brazil. Work, Employment and Society. UK: Cambridge University Press, v. 14, $\mathrm{n}^{\circ} 2$, p. 265-282, junho de 2000.

., GITAHY, L., RAMALHO, J.R., RUAS, R

(2000) "Produção Flexível e Relações Inter-firmas: A indústria de autopeças em três regiões do Brasil”. In ABREU, A. (Orgs.), Produção flexível e novas institucionalidades na América Latina. Editora da UFRJ, Rio de Janeiro. .e RAMALHO, J.R. (2000) A indústria automobilística brasileira e a implantação de novos pólos de desenvolvimento regional - o caso do Rio de Janeiro. III Congreso Latinoamericano de Sociología del Trabajo.Buenos Aires - 17 al 20 de Mayo de 2000.

. e Regional development and new labor strategies: trade unions and the new car plants in Resende, Brazil. In: DAN CORNFIELD e MCCAMMON H. (Orgs).. Labor Revitalization: global perspectives and new initiatives. v. 11 (in the book series, Research in the Sociology of Work), London: Elsevier, 2003.

ARBIX, G. (2000) Guerra Fiscal e Competição Intermunicipal por Novos Investimentos no Setor Automotivo Brasileiro. Dados, v. 43, n ${ }^{\circ} 1$, Rio de Janeiro.

.e ZILBOVICIUS, M. O Consórcio Modular da VW: um novo modelo de produção?, In: ARBIX, G. e ZILBOVICIUS, M. De JK a FHC - a reinvenção dos carros. São Paulo: Scritta, 1997.

Atlas de Desenvolvimento Humano do Brasil em 2013, (2014). Disponivel em: <http://atlasbrasil. org.br/>. Acesso em 20 dez. 2014.

CASTELLS, M. A Sociedade em Rede . São Paulo: Paz e Terra. v.I, 1999.

DIAS, S. Dentro da usina mas fora da 'familia': trabalhadores e terceirização na Companhia Siderúrgica Nacional (CSN). Mestrado (dissertação em Ciências Sociais), PPGSA-IFCS-UFRJ, Rio de Janeiro, 2010.

DIEESE ABC. Do salário às compras. São Paulo, 2007.

FREYSSENET, M.; LUNG, Y. Between globalization and regionalization: what is the futures of the automobile industry? Actes du GERPISA - 18 . EvryFrance:Université de Evry, 1997.

GRACIOLLI, E. J. Um caldeirão chamado CSN: resistência operária e violência militar na greve de 1988. Uberlândia: Editora da Universidade Federal de Uberlândia. 1997..

.Privatização da CSN: da luta de classes à parceria. São Paulo: Expressão Popular, 2007. 
HENDERSON, J. et. al. Redes de Produção Globais e a análise do desenvolvimento econômico. Revista Pós Ciências Sociais (UFMA), n¹5, p. 143-170, 2011.

MARTIN, S. Globalização e imbricamento da flexibilidade do trabalho: perspectivas contemporâneas da indústria automobilística nas Américas (Brasil, México e Estados Unidos”. In: GUIMARÃES, N.; MARTIN, S. (Orgs.) Competitividade e Desenvolvimento: atores e instituições locais(.). São Paulo: Editora Senac, 2001.

MONTEIRO, C. F.; LIMA, R. J. C.. Entidades empresariais e desenvolvimento no Sul Fluminense: governança, estratégia e estrutura, In: Revista Pós Ciências Sociais (UFMA), no 24, p.101-115, 2015.

PEREIRA, S. E.M. (2007), Sindicalismo e privatização: o caso da Companhia Siderúrgica Nacional., Tese (Doutorado em Ciências Sociais). Rio de Janeiro: PPGS-IFCS-UFRJ, 2007.

Programa das Nações Unidas para o Desenvolvimento (PNUD), Instituto de Pesquisa Econômica e Aplicada (IPEA) e Fundação João Pinheiro (FJP). Atlas de Desenvolvimento Humano do Brasil em 2013 (2014). Disponivel em: <http://atlasbrasil.org.br/>.

RAMALHO, J. R.. Fórum Demissão Zero: crise e ação coletiva no Sul Fluminense. In: RAMALHO, J.R. e FORTES, A. (Orgs.) Desenvolvimento, trabalho e cidadania: Baixada e Sul Fluminense.. Rio de Janeiro: 7 Letras, 2012.

.Novas conjunturas industriais e participação local em estratégias de desenvolvimento", Dados. Rio de Janeiro, v. 48, $\mathrm{n}^{\circ}$ 3, 2005, p. 147-178.

.SANTANA, M. A. A indústria automobilística no Rio de Janeiro: relações de trabalho em um contexto de desenvolvimento regional. In: NABUCO, M.R.; NEVES, M.A.; CARVALHO NETO, A.M. - (Orgs.). Indústria Automotiva: a nova geografia do setor produtivo. Rio de Janeiro, DPEtA Editora, 2002.

RODRIGUES, I.J e RAMALHO, J. R. Trabalho e Sindicato em antigos e novos territórios produtivos: comparações entre o ABC paulista e o Sul Fluminense. São Paulo: Annablume, 2007.
SANTOS, R.S.P. Redes de produção globais (RPGs): contribuições conceituais para a pesquisa em ciências sociais. Revista Pós Ciências Sociais (UFMA), $\mathrm{n}^{\circ}$ 15, p. 127-141, 2011.

SISTEMA FIRJAN. Índice Firjan de Desenvolvimento Municipal: ano base 2011. Disponivel em: <http://www.firjan.org.br/ifdm/>. Acesso em 20 jun. 2014.

SISTEMA FIRJAN. Índice Firjan de Desenvolvimento Municipal: ano base 2011. Disponivel em: $<$ http://www.firjan.org.br/ifdm/>. Acesso em 20 jun. 2014.

\section{Periódicos consultados}

Suspensão de contrato na MAN ou PDV, Boletim 9 de Novembro, 07 abr. 2014. Sindicato dos metalúrgicos do Sul Fluminense.

Sindicato prestigia inauguração da planta da Nissan em Resende. Boletim 9 de Novembro, $n^{\circ} 1102$, 25 abr. 2014. Sindicato dos metalúrgicos do Sul Fluminense

Salário do setor automotivo subirá menos. Diário do Vale, Volta Redonda, 31 maio 2014.

Resende participa de reunião do cluster automotivo, Diário do Vale, Volta Redonda, 13 nov. 2014.

Nissan afasta operários em Resende. Valor Econômico, São Paulo, 11 set. 2014.

Nissan produzirá novo motor no Rio. Valor Econômico, São Paulo, 07 jan. 2015.

Para Nissan, IPI dos carros terá de subir. Valor Econômico, São Paulo, 08 dez. 2014.

MAN pede agilidade do governo. Valor Econômico, São Paulo, 07 nov. 2014.

MAN volta a parar produção no RJ. Valor Econômico, São Paulo, 09 ago. 2014.

Governo estadual concede benefícios à MAN Latin America, Diário do Vale, Volta Redonda, 6 dez. 2014.

Fábrica de caminhões e ônibus completa dezoito anos. Diário do Vale. Volta Redonda: 03 nov. 2014. 
Demissões voluntárias na MAN Latin America começam amanhã. Diário do Vale, Volta Redonda, 10 dez. 2014.

A Voz da Cidade. Volta Redonda. Edições: 04 fev. 2009, 05 fev. 2009.

Sindicato vai denunciar demissões a Lupi - Sindicato dos Metalúrgicos aproveitará reunião para denunciar demissões em montadoras, Voz da Cidade, Volta Redonda, 05 fev. 2009.

Jaguar Land Rover começa obras no Rio, Valor Econômico, São Paulo, 25 out. 2014.

Nas cidades-polo do setor automotivo, desemprego já atinge outros setores, Valor Econômico, São Paulo, 16 out. 2014.

\section{Entrevistas}

Renato Soares, presidente do sindicato dos metalúrgicos de Volta Redonda, em 20 mar. 2009.

Vereador Mirim, da Câmara Municipal de Resende e ex-membro da Comissão de Fábrica da VW de Resende, em 16 abr. 2009. 


\section{RESUMO}

Duas décadas se passaram - 1996-2015 desde que o Sul Fluminense, região do Rio de Janeiro amplamente conhecida pela produção siderúrgica desde 1946, passou por uma reconfiguração de seu parque industrial com a implantação de fábricas da indústria automotiva. 0 impacto dos novos investimentos alterou substantivamente as atividades econômicas, políticas e administrativas regionais e fez crescer o mercado de trabalho formal, o ritmo de obras da construção civil e os recursos arrecadados pelos municípios. Incentivou também um debate sobre um projeto de desenvolvimento regional que explorasse a vocação metalmecânica introduzida pela vinda das grandes empresas e de suas fornecedoras. 0 texto pretende identificar e problematizar a “reinvenção" desse território produtivo já industrializado, tomando como base dados estatísticos que apontam melhorias em índices econômicos, sociais e do mercado de trabalho, mas também confirmam o uso sistemático de mão de obra barata como característica marcante das estratégias empresariais; e sugere uma discussão sobre a capacidade de interferência de empresas que fazem parte de "redes globais de produção" em processos de desenvolvimento regional, de modo a revelar um complexo conjunto de motivações e interesses associados a esses territórios produtivos, questionando qualquer análise unilateral sobre esses processos.

\section{PALAVRAS-CHAVE}

Territórios produtivos. Rio de Janeiro. Indústria automotiva. Empresas multinacionais. Mercado de trabalho. Desenvolvimento regional.

\section{ABSTRACT}

It has been two decades - 1996-2015 since the South Fluminense, region of the state of Rio de Janeiro, largely known by the steel production since 1946, has gone through a reconfiguration of its industrial park with the installation of plants of the automotive industry. The impact of the new investments has dramatically altered economic, political and administrative regional activities and made possible the growth of the labor market, of the building industry and of financial resources for the municipalities. It has also encouraged a debate on a regional development project that would stress the metal-mechanic vocation introduced by the big companies and their suppliers. The text intends to identify and problematize the "reinvention" of this already industrialized productive territory, using statistical data that reveal improvements in social and economic indexes and in the labor market, but also confirms the systematic use of cheap labor as a fundamental feature of the companies' strategies. It also suggests a discussion over the capacity of companies, which are part of "global production networks", to interfere in processes of regional development, in order to reveal the complex set of motivations and interests that are associated with productive territories, and the need to avoid unilateral evaluation of those processes.

\section{KEYWORDS}

Productive territories. Rio de Janeiro. Automotive industry. Multinational companies. Labor market. Regional development. 
